\title{
Roles of Dietary Cobalt and Administration of Mixed Rumen Bacteria in Regulating Hematological Parameters of Pre-weaning Twin Lambs
}

\author{
T. Adelina $a^{\mathrm{a}, \mathrm{b}, *, \S}$, A. Boediono ${ }^{\mathrm{c}, \sharp}$, I. G. Permana ${ }^{\mathrm{d}, \sharp}$, T. R. Wiradarya ${ }^{\mathrm{b}, \$}$, D. Evvyernie ${ }^{\mathrm{d}, \sharp}$, \& T. Toharmat $^{\mathrm{d}, \sharp}$ \\ ${ }^{a}$ Major Program of Animal Nutrition and Feed Science, Graduate School, Bogor Agricultural University \\ bStudy Program of Animal Science, Faculty of Agriculture and Animal Science, \\ State Islamic University of Sultan Syarif Kasim Riau \\ $\S$ Jln. H.R. Soebrantas Km 16 Panam, Pekanbaru 28293, Indonesia \\ 'Department of Anatomy, Physiology, and Pharmacology, Faculty of Veterinary Medicine, \\ Bogor Agricultural University \\ ${ }^{\mathrm{d}}$ Department of Nutrition and Feed Technology, Faculty of Animal Science, Bogor Agricultural University \\ "Jln. Agatis, Kampus IPB Darmaga, Bogor 16680, Indonesia \\ (Received 18-03-2013; Reviewed 17-04-2013; Accepted 13-06-2013)
}

\begin{abstract}
Cobalt (Co) is required by rumen microorganism for vitamin $B_{12}$ synthesis. Vitamin $B_{12}$ is an important cofactor for methionine synthesis and gluconeogenesis. In young ruminants up to 6-8 wk old, the rumen has not been completely developed and rumen microorganisms are not ready to supply vitamin $B_{12}$. The aim of this research was to determine the potency of mixed rumen bacteria and dietary supplementation of Co and its effect on plasma glucose, blood minerals (Co, Fe, and Zn) concentrations, and hematology of pre-weaning twin lambs. Twelve one month-old local twin lambs were assigned to 4 groups in a randomized complete block design. Lambs were fed cow milk at $10 \%$ body weight, adjusted weekly for $80 \mathrm{~d}$. Mixed rumen bacteria were offered at $15 \mathrm{~mL} / \mathrm{d}\left(8.295 \times 10^{10} \mathrm{cfu}\right)$. Dietary treatments were: 1) basal diet (Control), 2) basal diet $+1 \mathrm{mg} / \mathrm{kg} \mathrm{DM}$ cyanocobalamin $\left(\mathrm{VitB}_{12}\right)$ and 3) basal diet $+1 \mathrm{mg} / \mathrm{kg}$ DM of Co + administration of $15 \mathrm{~mL}$ mixed rumen bacteria (CoBac). There were no treatment effects on neither plasma glucose and blood mineral concentrations nor hematological profiles. This study demonstrated that pre-weaning twin lambs are not responsive to supplementation of Co and administration of mixed rumen bacteria.
\end{abstract}

Key words: blood, cobalt, lamb, rumen bacteria, vitamin $B_{12}$

\section{ABSTRAK}

Kobalt (Co) dibutuhkan mikrob rumen untuk mensintesis vitamin $B_{12}$. Vitamin $B_{12}$ berperan dalam sintesis metionin dan glukoneogenesis. Ruminansia berumur di bawah 6-8 minggu belum dapat mensintesis vitamin $B_{12}$ karena rumen belum berkembang optimal. Tujuan penelitian adalah menggali informasi mengenai potensi campuran bakteri rumen dan Co dalam mengatur glukosa plasma, mineral (Co, Fe, dan Zn) darah, serta hematologi pada anak domba kembar prasapih. Sebanyak 12 ekor anak domba lokal kembar prasapih umur 1 bulan dibagi dalam 4 kelompok dengan rancangan acak kelompok (RAK). Anak domba mendapat susu sapi $10 \%$ bobot badan. Campuran bakteri rumen diberikan $15 \mathrm{~mL} / \mathrm{h}\left(8,295 \times 10^{10} \mathrm{cfu}\right)$. Perlakuan terdiri atas: 1) ransum basal (kontrol), 2) ransum basal + suplementasi vitamin $B_{12}$ sintetis $1 \mathrm{mg} / \mathrm{kg} B K\left(\mathrm{VitB}_{12}\right)$, dan 3) ransum basal + Co 1 $\mathrm{mg} / \mathrm{kg}$ BK + $15 \mathrm{~mL}$ campuran bakteri rumen (CoBac). Glukosa plasma, mineral Co, Fe, dan Zn serta hematologi tidak berbeda antar perlakuan. Pemberian vitamin $B_{12}$ maupun CoBac tidak mengubah konsentrasi glukosa plasma, status mineral Co, Fe dan Zn serta mempertahankan hematologi normal pada domba kembar prasapih. Penelitian ini memperlihatkan bahwa anak domba kembar prasapih tidak responsif terhadap suplementasi Co dan campuran bakteri rumen.

Kata kunci: darah, kobalt, domba, bakteri rumen, vitamin $B_{12}$

*Corresponding author:

E-mail: trianiadelina@yahoo.com 


\section{INTRODUCTION}

Twin born lambs tend to have a low birth weight that causes a trouble in regulating body temperature and are more susceptible to infection, which may increase risk for a high mortality rate. Improvement of nutrient intake and immune system status by dietary supplementation of $\mathrm{Co}$ or vitamin $\mathrm{B}_{12}$ increased body weight of ruminant (Yousuf et al., 2009; Rusmana et al., 2002; Tiffany \& Spears, 2005).

Rumen microbes require Co for a corrin ring structure during vitamin $B_{12}$ synthesis. Vitamin $B_{12}$ is essential as a cofactor for methylmalonyl-CoA mutase and methionine synthase on gluconeogenesis and methionine synthesis. A general function of vitamin $B_{12}$ is to promote red blood cell synthesis and to maintain nervous system integrity (Hershko et al., 2006; Hvas \& Nexo, 2006; Mc Dowell, 2003). Deficiency in Co decreases microbial rumen population, limits the amount of available vitamin $\mathrm{B}_{12}$ to microbes and host animal (Tiffany et al., 2003) and results in reduce intake and average daily gain (Wang et al., 2007). Hershko et al. (2006) also showed that vitamin $\mathrm{B}_{12}$ deficiency may be preceded by Fe deficiency.

Ruminant have the ability to synthesize vitamin $\mathrm{B}_{12}$ if they are supplied by an adequate dietary Co and have a rumen that function normally. Rumen becomes functional for synthesis of vitamin $B_{12}$ at 6-8 wk of age (McDowell, 2003). Supplementation of vitamin $B_{12}$ in the ration is needed by lambs because rumen is not completely developed. Therefore, vitamin $\mathrm{B}_{12}$ supplementation is necessary, especially to promote adaptation to fermentation products like propionate, which will be used as a source of energy through gluconeogenesis and lambs survival.

The aim of this research was to determine the potency of mixed rumen bacteria and dietary supplementation of $\mathrm{Co}$ and its effect on plasma glucose, blood mineral (Co, Fe and $\mathrm{Zn}$ ) concentrations and hematological parameters of pre-weaning twin lambs.

\section{MATERIALS AND METHODS}

\section{General}

Twelve one month-old local twin lambs were assigned into three groups of four lambs in a randomized complete block design. The basal diet consisted of corn meal, pollard, soybean meal, molases, mix mineral dan crude palm oil (CPO) and was formulated to meet the nutrients requirement of lambs (NRC, 2007). Total basal crude protein diet was $20.78 \%$ DM and TDN was $83.56 \%$ DM (Table 1). The lambs had ad libitum access to feed and water during experimental period. Lambs were fed cow milk at $10 \%$ body weight, adjusted weekly for 80 days and fed in the morning and afternoon. Mixed rumen bacteria was offered at $15 \mathrm{~mL} / \mathrm{d}\left(8.295 \times 10^{10} \mathrm{cfu}\right)$ after morning milk feeding. Mixed rumen bacteria that used in this reseach was a mixture of 6 rumen bacteria isolates grown in Brain Heart Infusion medium with a 6 hours incubation period. Lambs were housed in individual metabolize cages of $115 \times 57 \times 175 \mathrm{~cm}^{3}$, and each cage was equipped with a feeder and a water trough. Treatments consisted of : 1) basal diet (control), 2) basal diet $+1 \mathrm{mg} / \mathrm{kg} \mathrm{DM}$ cyanocobalamin ( vitB $_{12}$ ), and 3) basal diet $+1 \mathrm{mg} / \mathrm{kg} \mathrm{DM}$ of Co + administration of 15 $\mathrm{mL}$ mixed rumen bacteria ( $\mathrm{CoBac})$. The ingredient and composition of the basal diet are shown in Table 1.

\section{Data Collections and Sample Analysis}

Blood samples were collected on day 53 of the experimental period. Blood samples were collected $4 \mathrm{~h}$ after feeding, via jugular venipuncture into heparinized tubes for determination of plasma glucose and blood mineral ( $\mathrm{Co}, \mathrm{Fe}$, and $\mathrm{Zn})$ concentrations and hematological parameters. Whole blood concentrations of $\mathrm{Co}, \mathrm{Fe}$, and $\mathrm{Zn}$ were determined by atomic absorption spectrophotometry (Shimadzu 25000) according to AOAC (2003). Plasma glucose was determined by GOD-PAP Methods (HUMAN, Human Gesellschaft fur Biochemica und Diagnostica $\mathrm{mbH}$, Germany). The hematological variables including packed cell volume (PVC), red blood cell (RBC), white blood cell (WBC), and the differentiation of WBC (neutrophils, lymphocytes, monocytes and eusinophils) were determined according to Sastrasdipraja et al. (1989) and Hemoglobin ( $\mathrm{Hb})$ was determined by Mercktest.

Data were analyzed as a randomized complete block design according to the method described by Steel \& Torrie (1993). Data were presented as means \pm standard error.

\section{RESULTS AND DISCUSSION}

Initial and final body weights in this study were similar among treatments (Table 2). The lambs were in

Table 1. Feed ingredient composition of basal diet offered to pre-weaning twin lambs (\% DM)

\begin{tabular}{lrrrrrrrrr}
\hline Ingredients & $\%$ & DM & Ash & OM & CP & CF & EE & NFE & TDN \\
\hline Corn meal & 45.00 & 39.78 & 0.44 & 44.56 & 4.39 & 0.58 & 1.98 & 37.62 & 38.44 \\
Pollard & 15.00 & 13.36 & 0.76 & 14.24 & 2.32 & 1.24 & 0.57 & 10.11 & 11.51 \\
Soybean meal & 30.00 & 26.41 & 2.03 & 27.97 & 13.98 & 0.95 & 0.47 & 12.57 & 28.46 \\
Molases & 8.53 & 4.88 & 0.64 & 7.89 & 0.09 & 0.00 & 0.08 & 7.71 & 5.16 \\
Mix mineral & 0.47 & 0.47 & 0.47 & - & - & - & - & - & - \\
CPO & 1.00 & 1.00 & - & 1.00 & - & - & 1.00 & - & - \\
T O T A L & 100.00 & 85.91 & 4.34 & 95.66 & 20.78 & 2.77 & 4.09 & 68.01 & 83.56 \\
\hline
\end{tabular}


a similar physiological condition. In the period of milk feeding, DM intake (concentrate and milk) of lambs were not differences among treatments. The same DM intake resulted in the same final body weight and body weight gain of twin lambs.

Plasma glucose and whole blood mineral (Co, Fe, and $\mathrm{Zn}$ ) concentrations are shown in Table 2. The mean of plasma glucose concentration in pre-weaning lambs at 67 days old was $65.65 \pm 9.21 \mathrm{mg} / \mathrm{dL}$. Plasma glucose of lambs in pre-weaning period were not affected by vitB $_{12}$ and $\mathrm{CoBac}$ treatments $(\mathrm{P}>0.05)$. However, plasma glucose concentration in the present study was related to DM intake of twin lambs. The same glucose plasma concentration was likely the result of the same feed intake among group of lambs in the treatments (Table 2). The same DM intake and glucose plasma concentration was the reason for the same final body weight of twin lambs (Table 2).

Glucose plasma concentration in the present study was in contrary to the report of Wang et al. (2007). They reported that dietary supplementation at $0.25,0.50,0.75$, and $1.00 \mathrm{mg} \mathrm{Co} / \mathrm{kg}$ DM in weaned lambs of Chinese Poll Dorset $x$ Small Tailed Han fed basal diet containing 0.086 mg increased glucose plasma concentration. Bishehsari et al. (2010) reported that the study in Mehraban male lambs fed a basal diet supplied with $0,0.25,0.5,0.75$, and $1 \mathrm{mg} \mathrm{Co} / \mathrm{kg}$ DM for $70 \mathrm{~d}$ showed a significant increase in plasma glucose concentration at all level of Co supplementation on day 68 of the experiment period. Tiffany \& Spears (2005) also indicated that addition of Co to basal diet increased plasma glucose concentration of steers.

The data indicated that supplementation vitamin $\mathrm{B}_{12}$ and CoBac to twin lambs at level of $1 \mathrm{mg}$ cyanocobalamin/kg DM and $1 \mathrm{mg} \mathrm{Co} / \mathrm{kg} \mathrm{DM}+$ mixed rumen bacteria was not sufficient to increased the availability of glucose precursor supplied by rumen and gluconeogenesis. Burgess et al. (2009) explained that vitamin $\mathrm{B}_{12}$ stimulated the activity of methylmalonyl CoA mutase and methionine synthase in gluconeogenesis. The result indicated that to meet energy requirement, pre-weaning

Table 2. Body weight, intake, plasma glucose and whole blood mineral in pre-weaning twin lambs

\begin{tabular}{lrrr}
\hline & \multicolumn{3}{c}{ Treatments } \\
\cline { 2 - 4 } Parameter & \multicolumn{1}{c}{ Control } & \multicolumn{1}{c}{ VitB12 } & \multicolumn{1}{c}{ CoBac } \\
\hline Initial body weight $(\mathrm{kg})$ & $4.65 \pm 2.40$ & $4.53 \pm 0.94$ & $4.83 \pm 1.69$ \\
Final body weight $(\mathrm{kg})$ & $7.38 \pm 3.46$ & $7.45 \pm 0.66$ & $7.88 \pm 1.54$ \\
Average daily gain $(\mathrm{kg})$ & $90.83 \pm 47.09$ & $97.50 \pm 23.15$ & $101.67 \pm 17.53$ \\
Intake (g/kg BW $\left.{ }^{0.75}\right):$ & & & \\
\multicolumn{1}{c}{ Dry matter : } & $52.77 \pm 5.55$ & $48.37 \pm 5.55$ & $53.66 \pm 5.55$ \\
$\quad$ Concentrate & $32.11 \pm 6.35$ & $29.03 \pm 6.35$ & $34.20 \pm 6.35$ \\
$\quad$ & $20.66 \pm 1.12$ & $19.34 \pm 1.12$ & $19.46 \pm 1.21$ \\
Milk & & & \\
(mg/dL) & $70.29 \pm 5.49$ & $59.66 \pm 5.49$ & $67.01 \pm 4.46$ \\
Co (ppm) & $0.11 \pm 0.05$ & $0.27 \pm 0.05$ & $0.22 \pm 0.04$ \\
Fe (ppm) & $463.89 \pm 32.25$ & $515.69 \pm 32.25$ & $538.49 \pm 26.21$ \\
Zn (ppm) & $1.32 \pm 0.40$ & $2.18 \pm 0.40$ & $2.56 \pm 0.33$ \\
\hline
\end{tabular}

twin lambs need higher supplementation of vitamin $B_{12}$ or Co.

Plasma glucose concentrations in this study were higher than adult sheep. Astuti et al. (2011) noted that blood glucose from sheep fed tropical browse plants was 37.5-59.49 mg/dL. Poore et al. (2007) stated that normal concentration of plasma glucose in sheep was $57.6 \mathrm{mg} / \mathrm{dL}$. However Abdelrahman (2010) reported the higher serum glucose concentration, that was 185 $\mathrm{mg} / \mathrm{dL}$, in Awassi lambs weaned at $60 \mathrm{~d}$ old and supplemented with direct-fed microbial. Udum et al. (2008) also reported that plasma glucose concentration from lambs with different feeding regimens was $107.2 \mathrm{mg} / \mathrm{dL}$. Wang et al. (2010) noted that plasma glucose from lambs fed with supplemental $0.3 \mathrm{mg} \mathrm{Co} / \mathrm{kg}$ DM was $64.98 \mathrm{mg} / \mathrm{dL}$.

Blood $\mathrm{Co}, \mathrm{Fe}$, and $\mathrm{Zn}$ concentrations of pre-weaning twin lambs did not differ among treatments (Table 2). Blood $\mathrm{Co}, \mathrm{Fe}$, and $\mathrm{Zn}$ were unlikely as indicators for determination of vitamin $B_{12}$ status in lambs. Data also showed that Co supplementation did not interfere Fe and $\mathrm{Zn}$ status. Even though blood Co concentration of lambs were slightly above the normal range, but the levels were in the safe range. Abdelrahman (2012) reported that $\mathrm{Co}$ and $\mathrm{Zn}$ serum concentrations of growing lambs ranged between 0.09-0.16 ppm and 0.97-2.68 ppm. Antunovic et al. (2012) noted that blood Fe concentration from lambs ranged from $1,641.90$ to $2,083.65 \mathrm{ppm}$. The blood Co status indicated that dietary $1 \mathrm{mg} \mathrm{Co} / \mathrm{kg} \mathrm{DM}$ was sufficient to meet the requirement of lambs.

Hematological of pre-weaning twin lambs are presented in Table 3 . The hematological variables including $\mathrm{Hb}, \mathrm{PVC}, \mathrm{RBC}, \mathrm{WBC}$, and the differentiation of WBC (neutrophils, lymphocytes, monocytes and eusinophils) during pre-weaning period were not affected by $\mathrm{VitB}_{12}$ and CoBac treatments. The result indicated that the dietary supplementation did not influence hematological parameter.

The PVC, RBC and $\mathrm{Hb}$ values in the present study were higher than the previous studies. It assumed that level vitamin $B_{12}$ and $C o$ in this study was already sufficient to promote red blood cells formation in pre-weaning twin lambs. Wang et al. (2009) reported that PVC,

Table 3. Blood hematological of pre-weaning twin lambs

\begin{tabular}{lrcc}
\hline \multirow{2}{*}{ Parameter } & \multicolumn{3}{c}{ Treatments } \\
\cline { 2 - 4 } & Control & VitB12 & CoBac \\
\hline $\mathrm{Hb}(\mathrm{g} \%)$ & $9.52 \pm 1.04$ & $12.72 \pm 1.04$ & $12.48 \pm 0.84$ \\
$\mathrm{PVC}(\%)$ & $26.88 \pm 3.65$ & $36.63 \pm 3.65$ & $34.13 \pm 2.97$ \\
$\mathrm{RBC}(106 / \mathrm{mm})$ & $12.87 \pm 1.15$ & $13.81 \pm 1.15$ & $14.86 \pm 0.93$ \\
WBC $(103 / \mathrm{mm} 3)$ & $13.97 \pm 3.13$ & $10.71 \pm 3.13$ & $8.60 \pm 2.55$ \\
WBC differentiation $(\%):$ & & & \\
\multicolumn{1}{c}{ Lymphocytes } & $57.92 \pm 15.58$ & $42.52 \pm 15.58$ & $66.00 \pm 12.66$ \\
$\quad$ Neutrophils & $34.48 \pm 17.01$ & $48.88 \pm 17.01$ & $26.25 \pm 13.82$ \\
$\quad$ Monocytes & $4.31 \pm 0.77$ & $1.91 \pm 0.77$ & $3.25 \pm 0.63$ \\
\multicolumn{1}{c}{ Eusinophils } & $3.30 \pm 1.99$ & $6.70 \pm 1.99$ & $4.50 \pm 1.62$ \\
\hline
\end{tabular}

Note: $\mathrm{PVC}=$ packed cell volume; $\mathrm{RBC}=$ red blood cell; $\mathrm{WBC}=$ white blood cell. 
$\mathrm{RBC}$ and $\mathrm{Hb}$ of lambs offered diet supplemented with $1 \mathrm{mg}$ Co $/ \mathrm{kg}$ DM diet were $33.88 \% ; 11.01 \times 10^{6} / \mathrm{mm}^{3}$ and 9.68\%-10.48 g\%, respectively. Marca et al. (1996) reported that blood $\mathrm{Hb}$ of lambs injected with $1 \mathrm{mg}$ cyanocobalamin during the first week of life was $9.1 \%-11.8 \mathrm{~g} \%$.

PVC, $\mathrm{RBC}$, and $\mathrm{Hb}$ in the present study were contrast with Johnson et al. (2004). They reported that weaned goats fed with dietary $0.12 \mathrm{mg} \mathrm{Co} / \mathrm{kg} \mathrm{DM}$ and bi-monthly subcutaneous injections of $2000 \mu \mathrm{g}$ of hydroxycobalamin exhibited declined in erythrocyte counts, hemoglobin and PVC. Johnson et al. (2010) also reported that dietary $0.1 \mathrm{mg} \mathrm{Co} / \mathrm{kg} \mathrm{DM}$ and bimonthly subcutaneous injections on $2000 \mu \mathrm{g}$ hydroxycobalamin resulted in an early impairment of phagocytic function.

Hemoglobin values obtained in this study were related to blood Fe concentration (Table 2). Fe is required for hemoglobin synthesis in the bone marrow (Moosavian et al., 2010). The result indicated that dietary vitamin $B_{12}$ and $C o$ had no negative effect on $F e$ and were sufficient to maintain normal level of $\mathrm{RBC}$ and $\mathrm{Hb}$ of twin lambs.

WBC and WBC differentiation including lymphocytes, neutrophils, monocytes and eusinophils on preweaning twin lambs were not affected by vitB $B_{12}$ and CoBac treatments. WBC of the lambs in the control treatment were slightly higher than the normal range, while the lambs in vitB ${ }_{12}$ and $\mathrm{CoBac}$ had the normal level of WBC. Goats (Al-Habsi et al., 2007) and preweaning calves offered with rumen bacteria concortium (Prihantoro et al., 2013) in both sufficient and deficient Co had the same WBC values. Lack of effect of treatments on blood cells may indicate that supplementation vitamin $\mathrm{B}_{12}$ and $\mathrm{Co}$ as $1 \mathrm{mg} / \mathrm{kg} \mathrm{DM}$ did not influence WBC and WBC differentiation.

Hematological parameter including $\mathrm{Hb}, \mathrm{PVC}, \mathrm{RBC}$, and WBC differentiation in pre-weaning twin lambs period were in the normal range. Kramer \& Byers (2011) reported the normal range of $\mathrm{RBC}, \mathrm{Hb}$ and $\mathrm{PVC}$ were

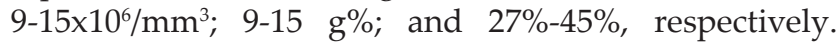
Normal range for $\mathrm{WBC}$ and its components are WBC $4-12 \times 10^{3}$, lymphocytes $40 \%-55 \%$, neutrophils $10 \%-50 \%$, monocytes $0 \%-6 \%$, and eusinofil $0 \%-10 \%$, but lambs within 3 mo of ages, lymphocytes represent $70 \%-80 \%$ of the total WBC population.

\section{CONCLUSION}

Dietary supplementation of vitamin $\mathrm{B}_{12}$ and Co accompanied by the administration of mixed rumen bacteria do not influence weight gain, plasma glucose concentration, blood $\mathrm{Co}, \mathrm{Fe}$, and $\mathrm{Zn}$ concentration and maintaining normal hematological parameters of pre-weaning twin lambs. This study demonstrated that pre-weaning twin lambs are not responsive to supplementation of $\mathrm{Co}$ and administration of mixed rumen bacteria.

\section{REFERENCES}

Abdelrahman, M. M. 2010. Effect of direct-fed microbial (DFM) ${ }^{\circledR}$ supplements on general performance of newborn awassi lambs. Eg. J Sh. \& G Sci. 5: 249-266.
Abdelrahman, M. M. 2012. Status of some minerals of growing Awassi lambs fed calcium salt fat and protected sulfur amino acid. J. Anim \& Plant Sci. 13: 1698-1703.

Al-Habsi, K., E. H. Johnson, I. T. Kadim, A. Srikandakumar, K. Annamalai, R. Al-Busaidy, \& O. Mahgoub. 2007. Effects of low concentrations of dietary cobalt on livewight gains, haematology, serum vitamin B12 and biochemistry of omani goats. T. Vet J. 173: 131-137. http://dx.doi. org/10.1016/j.tvjl.2005.10.002

[AOAC] Association of Official Analytical Chemist. 2003. Official Methods of Analysis of the Association of Official's Analytical Chemists. 17th Ed. Association of Official Analytical Chemist, Arlington.

Antunovic, Z., M. Speranda, D. Sencic, J. Novoselec, Z. Steiner, \& M. Djidara. 2012. Influence of age on some blood parameters of lambs in organic production. Maced. J. Anim. Sci. 2: 11-15.

Astuti, D. A., A. S. Baba, \& I. W. T. Wibawan. 2011. Rumen fermentation, blood metabolites and performance of sheep fed tropical browse plants. Med. Pet. 34: 201-206. http:// dx.doi.org/10.5398/medpet.2011.34.3.201

Bishehsari, S., M. M. Tabatabaei, H. Aliarabi, D. Alipour, P. Zaman, \& A. Ahmadi. 2010. Effect of dietary cobalt supplementation on plasma and rumen metabolites in mehraban lambs. Small Ruminant Research 90: 170-173. http://dx.doi. org/10.1016/j.smallrumres.2010.02.010

Burgess, C. M., E. J. Smid, \& D. Van Sinderen. 2009. Bacterial vitamin B2, B11 and B12 overproduction: An overview. Inter. J. Food Microbiology 133: 1-7. http://dx.doi. org/10.1016/j.ijfoodmicro.2009.04.012

Hershko, C., A. Ronson, M. Souroujon, I. Maschler, J. Heyd, \& J. Patz. 2006. Variable hematologic presentation of autoimmune gastritis: age-related progression from iron deficiency to cobalamin depletion. Blood 107: 1673-1679. http://dx.doi.org/10.1182/blood-2005-09-3534

Hvas, A.M. \& E. Nexo. 2006. Diagnosis and treatment of vitamin B12 deficiency, An update. Haematologica 91: 1506-1512.

Johnson, E. H., K. Al-Habsi, E. Kaplan, A. Srikandakumar, I. T. Kadim, K. Annamalai, R. Al-Busaidy, \& O. Mahgoub. 2004. Caprine hepatic lipidosis induce through the intake of low levels of dietary cobalt. The Vet. J. 168: 174-179. http://dx.doi.org/10.1016/j.tvj1.2003.10.012

Johnson, E. H., K. Al-Habsi, R. Al-Busaidy, \& S. K. Khalaf. 2010. The effect of low levels of dietary cobalt on the chemiluminescence response of polymorphonuclear leukocytes of goats. Research Vet. Sci. 88: 61-63. http://dx.doi. org/10.1016/j.rvsc.2009.06.008

Kramer, J. W. \& S. R. Byers. 2011. Schalm's Veterinary Hematology. 6th ed. Douglas, D. J. \& K. J. Wardrop (Ed). WileyBlackwell, Philadelphia.

Marca, M. C., J. J. Ramos, T. Saez, M. C. Sanz, M. T. Verde, \& A. Fernandez. 1996. Vitamin B12 supplementation of lambs. Small Ruminant Research 20: 9-14. http://dx.doi. org/10.1016/0921-4488(95)00772-5

McDowell, L. R. 2003. Minerals in Animal and Human Nutrition. Elsevier Science B.V, Amsterdam.

Moosavian H. R., M. Mohri, \& H. A. Selfi. 2010. Effects of parenteral over- supplementation of vitamin A and iron on hematology, iron biochemistry, weight gain and health of neonatal dairy calves. Food Chem. Toxicol. 48: 1316-1320. http://dx.doi.org/10.1016/j.fct.2010.02.030

[NRC] National Research Council. 2007. Nutrient Requirement of Small Ruminants : Sheep, Goats, Cervids and New World Camelids. National Academic Press, Washington.

Poore, K. R., J. K. Cleal, J. P. Newman, J. P. Boullin, D. E. Noakes, M. A. Hanson, \& L. R. Green. 2007. Nutritional challenges during development induce sex-specific changes in glucose homeostasis in the adult sheep. Am. J. Physiol Endocrinol Metab. 292: E32-E39. http://dx.doi.org/10.1152/ 
ajpendo.00253.2006

Prihantoro, I., D. Evvyernie, Suryani, L. Abdullah, N. S. Yunitasari, A. P. Sari, D. Khairunisa, A. Haziq, N. Rahayu, \& T. Toharmat. 2013. Potensi bakteri pencerna serat asal rumen kerbau yang diinokulasikan pada pedet frisian holstein selama periode prasapih. JITV 17: 297-309.

Rusmana, D., D. Latifudin, \& A. Budiman. 2002. Pengaruh suplementasi kobalt dan vitamin B12 terhadap pertambahan bobot badan, konsumsi bahan kering dan efisiensi penggunaan pakan domba priangan. J. I. Ternak 2: 60-64.

Sastrasdipraja, D., S. H. S. Sikar, R. Widjajakusuma, T. Ungerer, A. Maad, H. Nasution, R. Suriawinata, \& R. Hamzah. 1989. Fisiologi Veteriner. Depdiknas PAU IPB, Jakarta.

Steel, R. G. D. \& J. H. Torrie. 1993. Prinsip dan Prosedur Statistika: Suatu Pendekatan Biometrik. Terjemahan: B. Sumantri. PT Gramedia, Jakarta.

Tiffany, M. E., J. W. Spears, L. Xi, \& J. Horton. 2003. Influence of supplemental cobalt source an concentration on performance, vitamin B12 status and ruminal and plasma metabolites in growing and finishing steers. J. Anim Sci. 81:3151-3159.

Tiffany, M. E. \& J. W. Spears. 2005. Differential responses to dietary cobalt in finishing steers fed corn vs barley-base diets. J Anim. Sci. 83:2580-2589.
Udum, D. C., M. Cetin, F. Balci, N. Gunes, \& C. Hecer. 2008. Effects of plasma insulin, glucose and NEFA concentration of feeding frequency during long term in lambs. J. Biol. Environ. Sci. 2: 45-51.

Wang, R. L., X. H. Kong, Y. Z. Zhang, X. P. Zhu, Narenbatu, \& Z. H. Jia. 2007. Influence of dietary cobalt on performance, nutrient digestibility and plasma metabolites in lambs. Anim. Feed Sci. Tech. 135: 346-352. http://dx.doi. org/10.1016/j.anifeedsci.2006.08.011

Wang, R. L., W. Zhang, Y. Z. Zhang, C. X. Zhang, J. B. Cheng, \& Z. H. Jia. 2009. Influence of dietary cobalt on vitamin B12, rumen fermentation and heme-depending blood parameters in lamb. Chinese J. Anim Sci. 19(5).

Wang, R. L., W. Zang, X. P. Zhu, \& Z. H. Jia. 2010. Influence of different rations of cobalt and copper supplementation on vitamin B12 status and nutrient utilization in sheep. Agri. Sci. in China 9: 1829-1835. http://dx.doi.org/10.1016/S16712927(09)60282-0

Yousuf, M. B., M. A. Belewu, \& A. H. A. Badmus. 2009. Effect of cobalt supplements on performance of Panicum maximum hay fed goats. Centrepoint Journal 16:1-6. 